\title{
O SENSÍVEL E O INTELIGÍVEL: MERLEAU-PONTY EO PROBLEMA DA RACIONALIDADE
}

\author{
Luiz Damon Santos Moutinho*
}

RESUMO Este artigo investiga a crítica merleau-pontiana ao idealismo moderno a partir do modelo reflexivo adotado por este último. Procura mostrar a necessidade em que o filósofo se vê de superar a separação entre o domínio da "sensibilidade" e do "entendimento", como condição para redefinir o problema da racionalidade. Procura mostrar ainda que a "reflexão radical" proposta por Merleau-Ponty, em oposição à reflexão idealista, leva-o a retomar as tarefas que outrora cabiam à metafísica clássica.

Palavras-chave Merleau-Ponty, idealismo, sensibilidade, entendimento, racionalidade

ABSTRACT This paper investigates Merleau-Ponty's criticism of modern idealism, which stems from the reflective model adopted by the latter. It aims at showing the need the philosopher has of going beyond the separation between the realm of "sensitivity" and the one of "understanding", as a condition to redefine the problem of rationality. It aims also at showing that the "radical reflection" proposed by Merleau-Ponty, as opposed to idealistic reflection, leads him to resume the tasks that used to be dealt with by classical metaphysics.

Key-words Merleau-Ponty, Idealism, sensitivity, understanding, rationality

* Professor da Universidade Federal do Paraná. Artigo recebido em fevereiro de 2004 e aprovado em março de 2004. (luizdamon@yahoo.com.br)

KRITERION, Belo Horizonte, ${ }^{\circ}$ 110, Dez/2004, p. 264-293 
Em 1959, ao passar em revista seu itinerário intelectual, Merleau-Ponty descreve brevemente a cena filosófica francesa das primeiras décadas do século $\mathrm{XX}^{1}$. E o que ele ali ressalta é a enorme influência que exercia então o pensamento de Léon Brunschvicg e, através dele, a "filosofia reflexiva". Por "filosofia reflexiva", Merleau-Ponty designa o idealismo moderno que ele faz remontar a Descartes e Kant. Mais que Brunschvicg, é esse idealismo que ele destaca como aquele que vai estar na origem da "filosofia da existência", de que ele próprio é um dos representantes. Em verdade, é "em reação" ao idealismo que a filosofia da existência se afirma. E ele ali destaca um tema que deve suscitar toda uma reforma da filosofia, tema que perpassa a totalidade de suas críticas ao idealismo, desde A estrutura do comportamento até $O$ visível $e$ o invisível: a reflexão. Na versão do idealismo vulgarizada por Brunschvicg, a tarefa da filosofia consistiria em um esforço de reflexão, de retorno do espírito sobre si mesmo, a partir do qual o espírito criador revela seus mecanismos:

\begin{abstract}
que se trate de nossa percepção dos objetos que nos envolvem ou que se trate da atividade dos sábios, em todos os casos, sua filosofia buscava apreender seja a percepção exterior, seja a construção da ciência, como o fato de uma atividade de espírito, uma atividade criadora e construtora do espírito. Era o tema verdadeiramente constante do pensamento de Brunschvicg, e para ele no fundo a filosofia consistia exatamente nisso: que o olhar, que nos cientistas é voltado para o objeto, se volte para o espírito que constrói seus objetos de ciência² .
\end{abstract}

A filosofia se coloca em uma perspectiva distinta da perspectiva da percepção e da do cientista, da perspectiva do senso comum e da perspectiva da ciência. Estas duas últimas são colocadas em um mesmo nível, na medida em que estão ambas voltadas para o objeto, para o mundo, e não para aquilo que faz o objeto, o mundo, vir a ser. Nesse sentido, a reflexão idealista não é uma reflexão qualquer, mas aquela que se conjuga a um outro tema, cerne do idealismo: o tema da constituição. Pois, se o objeto é constituído pelo espírito, a reflexão idealista consiste em uma recuperação das pegadas da constituição, em um esforço em coincidir com um naturante que é suposto desdobrar diante dele o mundo, como se essa restauração, essa re-constituição fosse a imagem em espelho da constituição efetiva, como o caminho de Étoile a Notre-Dame é o inverso do caminho de Notre-Dame a Étoile. Tudo se passa, nessa perspectiva - e Merleau-Ponty não cessará de notar isso —, como se a reflexão, para

1 MERLEAU-PONTY. A filosofia da existência. In: Parcours deux, p. 247-266.

2 Ibidem, p. 250. 
compreender nosso laço natal com o mundo, procurasse de início desfazer esse laço para refazê-lo em seguida. É essencial à filosofia reflexiva, portanto, nos recolocar aquém de nossa situação de fato, em um centro a partir do qual fazemos implicitamente aquilo que ela reconquista explicitamente ${ }^{3}$. Para Merleau-Ponty, a filosofia reflexiva tem razão em negar uma relação exterior entre um mundo em si e o sujeito concebido como processo no interior do mundo. Daí porque é necessário passar por ela. Mas resta saber se a via da constituição é a melhor alternativa. A constituição é, na versão definitiva de Merleau-Ponty, a tese idealista da relação entre sujeito e mundo, e essa tese implica para ele uma dupla transposição: a transposição do sujeito encarnado em sujeito transcendental e da realidade do mundo em idealidade ${ }^{4}$. Essa dupla transposição delineia o essencial do seu debate com o idealismo, para além da versão de Brunschvicg. Daí porque, contra ela, é necessário voltar ao fundamental, à relação entre sujeito e mundo, e mostrar uma dupla encarnação, a do sujeito e a do mundo. Diz Merleau-Ponty: "em reação a uma filosofia de tipo idealista, kantiano ou cartesiano, a filosofia da existência se traduziu para nós, de início, pela preponderância de um tema inteiramente outro, o tema da encarnação" 5 .

\section{II}

Descartes, antes de Kant, já traz a originalidade que importa ao fenomenólogo notar, pois já Descartes coloca-se no interior da percepção: Descartes, nas Meditações pelo menos, analisa não a visão e o tato como funções do corpo, mas o pensamento de ver e de tocar. Por isso mesmo, ele pode revelar "o domínio indubitável das significações"6. Para além dos fantasmas do realismo (a coisa sensível que nos afeta, o corpo como intermediário da ação causal dessa coisa), coisa e corpo passam a ser definidos como "significação coisa" e "significação corpo". A perspectiva que aí se inaugura é idealista no sentido em que a "indubitável” significação não vai além do domínio das essências, ela não nos dá mais que a "estrutura inteligível" dos objetos. Que na percepção o objeto se apresente sem ter sido querido, que haja nele um "índice existencial" que o distinga dos objetos do sonho, isso não conduz Descartes a abandonar o terreno purificado das essências, dando à significação um domínio mais largo: não, a experiência dessa "existência", dessa "presença sensível",

3 MERLEAU-PONTY. Le visible et l'invisible, p. 54-55.

4 Ibidem, p. 52.

5 MERLEAU-PONTY. A filosofia da existência. In: Parcours deux, p. 254.

6 MERLEAU-PONTY. La structure du comportement, p. 211. 
continua a ser explicada por uma excitação que leva a alma a pensar tal objeto "por um evento corporal ao qual ela 'se aplica' e que lhe 'representa' um evento da existência real" " . A reflexão cartesiana nos conduz, portanto, a um "universo de consciência" que é, e "em sentido restritivo, um universo de pensamento": esse universo dá conta do pensamento de ver, mas "o fato da visão e o conjunto dos conhecimentos existenciais permanecem fora dele". Descartes, apoiandose na matematização da natureza levada a cabo por Galileu, separa o sensível do inteligível, transformando-o em mero signo da existência das coisas ${ }^{8}$. O pedaço de cera não é apreendido pela sensibilidade, nem pela imaginação, mas por uma "inspeção do espírito": é o entendimento que o concebe, uma vez que ele foi despojado de suas qualidades sensíveis ${ }^{9}$. O sensível torna-se então apenas um signo, separado da significação, que é apreendida, por sua vez, pelo entendimento: "Descartes não procurou integrar o conhecimento da verdade e a experiência da realidade, a intelecção e a sensação. Não é na alma, é em Deus que elas se ligam uma à outra"10. O que faltou a Descartes, segundo Merleau-Ponty, foi integrar significação e existência não em Deus, como ele o fez, mas na própria experiência. Pois é essa integração que pode dar à percepção a autonomia diante do entendimento - autonomia necessária, se a percepção deve ser algo mais que uma simples função sensorial. Ou antes: autonomia necessária, se a experiência deve recobrar seus direitos face a um comentário intelectualista.

O comentário kantiano da percepção é diferente, já que não há ali a mediação do infinito. Kant preserva o domínio das significações, certamente, e portanto a percepção exige, também aqui, uma "análise interior". Mas, porque o acordo entre sentido e existência não é mais remetido a Deus, é forçoso concluir que "é a coisa mesma que eu atinjo na percepção, pois toda coisa na qual podemos pensar é uma 'significação de coisa' e chamamos justamente percepção o ato no qual essa significação se revela a mim"11. Ao contrário do que ocorre em Descartes, a percepção em Kant atinge, ela própria, a coisa: é com Kant, não com Bergson, assegura Merleau-Ponty, que se inaugura a idéia

7 Ibidem, p. 212

8 Essa versão do cartesianismo é a mesma difundida por Husserl. Cf. Krisis, \# 10 e \# 11.

9 "[...] desejaria quase concluir que se conhece a cera pela visão dos olhos e não pela tão-só inspeção do espírito, se por acaso não olhasse pela janela homens que passam pela rua, à vista dos quais não deixo de dizer que vejo homens da mesma maneira que digo que vejo a cera; e, entretanto, que vejo desta janela, senão chapéus e casacos que podem cobrir espectros ou homens fictícios que se movem apenas por molas? Mas julgo que são homens verdadeiros e assim compreendo, somente pelo poder de julgar que reside em meu espírito, aquilo que acreditava ver com meus olhos." (DESCARTES. Meditações metafísicas, p. 97).

10 MERLEAU-PONTY. La structure du comportement, p. 212-213.

11 Ibidem, p. 215. 
de que "a percepção do ponto O está no ponto O”. Vem daí que o que em Descartes era pura aparência, dissociada da essência, em Kant torna-se fenômeno: "para marcar ao mesmo tempo a intimidade dos objetos ao sujeito e a presença neles de estruturas sólidas que os distinguem das aparências, nós os chamaremos "fenômenos" "12. Mas será um tal fenômeno - pergunta-se o fenomenólogo - uma efetiva junção de essência e existência?

Não, certamente não. E aqui aparece uma objeção clássica de MerleauPonty, tantas vezes retomada, que vai valer também contra o Husserl da segunda fase, o Husserl de Idéias: o fenômeno kantiano, malgrado ultrapasse a pura aparência cartesiana, não integra a significação à existência, porque essa significação é produto de uma consciência constituinte. A análise do ato de conhecer em Kant, diz Merleau-Ponty, conduz a um "pensamento constituinte ou naturante que subtende interiormente a estrutura característica dos objetos"13 . Noutras palavras, Kant toma a consciência como "meio universal" e a percepção torna-se, por isso mesmo, "uma variedade da intelecção". Tudo se passa para Merleau-Ponty como se, diante de uma consciência naturante, esses conteúdos empíricos, essas coisas inertes que seriam as sensações puras, acabassem por se tornar uma "noção limite", o que anularia de vez a "consciência sensível": uma análise que desejasse isolar o conteúdo percebido nada encontraria,

porque toda consciência de alguma coisa, desde que esta coisa [...] é identificável e reconhecível [...] pressupõe, através da impressão vivida, a apreensão de um sentido que não está contido nela, não é dela uma parte real. A matéria do conhecimento torna-se uma noção limite posta pela consciência em sua reflexão sobre si mesma e não um componente do ato de conhecer ${ }^{14}$.

Que se frise bem: na versão merleau-pontiana do idealismo kantiano, a consciência se apresenta como naturante, não por relação ao ser do mundo, mas por relação à significação: o seu correlato não é o ser, mas o fenômeno; e se esse fenômeno se distingue da pura aparência, é justamente porque ele envolve a significação, de que a aparência é desprovida. No entanto, nota Merleau-Ponty, diante desse naturante o conteúdo tem necessariamente que se dissolver, pois a significação, vinda da consciência, não é produto de uma atividade lógica, de um simples juízo, e a percepção, portanto, não é uma simples "interpretação"15. Ela não pode mesmo ser uma interpretação, pois

12 Ibidem, p. 215.

13 Ibidem, p. 215.

14 Ibidem, p. 215, grifos nossos.

15 MERLEAU-PONTY. Phénoménologie de la perception, 1995 [Fenomenologia da percepção, 1994], p. 46; p. 66. (A primeira numeração de página refere-se à edição francesa; a segunda, à edição brasileira.)

16 Ibidem, p. 46-47; 66. 
não há, não pode haver nenhum dado prévio, nenhuma premissa sobre a qual o juízo se aplique: a sensação, a impressão vivida, já pressupõe a apreensão de um sentido e portanto o trabalho da consciência. Daí porque Merleau-Ponty inverte a posição desse dado supostamente originário:

a pura sensação [a premissa do juízo] definida pela ação dos estímulos sobre nosso corpo é o "efeito último" do conhecimento, em particular do conhecimento científico, e é por uma ilusão, aliás natural, que a colocamos no começo e acreditamos que seja anterior ao conhecimento [...] Pertence ao domínio do constituído e não ao espírito constituinte [...] Para a própria consciência, como ela seria um raciocínio se não existem sensações que possam servir de premissas, como ela seria uma interpretação se antes dela não há nada para ser interpretado ${ }^{16}$.

A partir daqui, a matéria tem que passar ao "limite" e tornar-se produto de uma ilusão retrospectiva, e o criticismo, finalmente, um idealismo transcendental, pois tudo, no final das contas, deve passar ao domínio do constituído. A perspectiva transcendental supera assim toda passividade, toda finitude; por isso, o sujeito transcendental é uma versão, entre outras, do "sujeito de sobrevôo". Na versão merleau-pontiana do idealismo, eu não poderia me perceber "envolvido por meu corpo" se eu não pudesse pensar essa relação e, por isso mesmo, escapar a essa inerência; eu não poderia me saber situado no mundo se estivesse realmente situado nele: "eu me limitaria a estar onde estou como uma coisa, e, se sei onde estou e me vejo no meio das coisas, é porque sou uma consciência, um ser singular que não reside em nenhum lugar e pode tornar-se presente a todas as partes em intenção"17. A percepção não está em parte alguma, como uma coisa, senão ela não poderia fazer as coisas existirem para ela, a percepção é apenas pensamento de perceber. Assim, a encarnação não oferece nenhum "caráter positivo", e pela simples razão de que a consciência transcendental força a matéria, a afecção, a consciência sensível, a passar ao limite: "se uma consciência constituinte universal fosse possível, a opacidade do fato desapareceria" 18 . Tudo se passa enfim como se o acordo entre o sensível e o inteligível não pudesse ser mantido, na medida em que ele se faz sob a égide do entendimento, como se o equilíbrio entre o "dado" e o "pensado" não pudesse ser sustentado. Em suma, a versão kantiana desse acordo que outrora se fazia em Deus ainda não é suficiente. Dizer, portanto, como Merleau-Ponty o faz, que a consciência transcendental kantiana é naturante não significa dizer que Kant (nem, analogamente, o "segundo Husserl") pretendesse afirmar uma 
consciência naturante do ser do mundo, mas apenas, como lhe é próprio, de uma significação do mundo - entretanto, é um tal acordo que se revela impossível, o acordo entre o dado e o pensado, a matéria e a forma, a passividade e a atividade, pois ele é pensado a partir de uma consciência que se afirma como "meio universal", como fonte da significação. Assim, o criticismo procuraria resolver "os problemas postos pelas relações entre a forma e a matéria, entre o dado e o pensado, entre a alma e o corpo, concluindo-se em uma teoria intelectualista da percepção"19. Por aqui, pode-se medir as distâncias que separam Merleau-Ponty daquela outra interpretação que vai apontar justamente em Kant o aparecimento de um sentido positivo da finitude. A estratégia de Merleau-Ponty, ao contrário, consiste em incluir Kant em um prejuízo geral - sobre o qual falaremos adiante — que é também o do dogmatismo.

Verdade que Merleau-Ponty pretende ver essa filosofia de inspiração criticista mais em Brunschvicg do que no próprio Kant. Aliás, já no debate acima, que pretende mostrar uma teoria intelectualista da percepção, a conclusão é remetida a Brunschvicg. É ele, não Kant, é o espiritualismo francês que, voltando-se para a percepção, pretende fazer dela uma "ciência iniciante", "uma primeira organização da experiência que só se conclui pela coordenação científica" ${ }^{20}$. Pois, afinal, se, segundo Merleau-Ponty, a segunda edição da Crítica da razão pura desequilibra o acordo entre o idealismo transcendental e o realismo empírico em favor do idealismo transcendental, é verdade também que essa leitura não esgota o interesse de Merleau-Ponty por Kant. Bem mais que a primeira, interessa a Merleau-Ponty a terceira Crítica, é ela que "contém indicações essenciais acerca dos problemas" de que trata o fenomenólogo. E que problemas são esses?

\section{III}

Não é de estranhar que a referência à Crítica do juízo apareça justamente no momento em que, contra o transcendental da filosofia de "inspiração criticista", Merleau-Ponty opõe a estrutura que nos é revelada pela Gestalttheorie. No prefácio à Fenomenologia da percepção, Merleau-Ponty retoma a comparação entre a primeira e a terceira Críticas, procurando frisar ali que justamente na terceira Crítica Kant descobre um acordo entre o sensível e o conceito, entre mim e outrem, que já não faz do sujeito "o pensador universal de um sistema de objetos rigorosamente ligados, a potência que sujeita o múltiplo à

20 Idem.

21 MERLEAU-PONTY. Phénoménologie..., p. XII-XIII; 15. 
lei do entendimento"; antes, ao contrário, esse sujeito se descobre como "uma natureza espontaneamente conforme à lei do entendimento", de modo que a unidade, isto é, a significação não é simplesmente posta, mas se faz em nível antepredicativo $^{21}$. Ora, é justamente esse modelo que Merleau-Ponty entende retomar através da estrutura, pois esta se revela a "junção de uma idéia e de uma existência indiscerníveis, o arranjo contingente pelo qual os materiais se põem diante de nós a ter um sentido"22 . Também aqui, o acordo entre o sensível e o conceito é "livre e indeterminado", ainda que, por ser veiculado pela estrutura, por já não se limitar ao juízo estético, ele se espalhe por toda a experiência, de modo que é toda a atividade categorial que se vê condicionada por ele, e portanto é todo o conhecimento que repousa nele. É no mundo percebi$d o$, finalmente, que se realiza um tal acordo. Ora, era baseado nessa virtude da forma que Merleau-Ponty fazia a defesa da Gestalttheorie face às críticas que Husserl dirigia a ela, quando a colocava ao lado da psicologia atomista do século XIX. Para Husserl, com efeito, não há diferença de princípio entre a consciência tomada como soma de átomos psíquicos e a consciência vista como totalidade na qual os elementos não têm existência separável. De um modo ou de outro, a consciência é ainda uma coisa, e não uma consciência. Ora, essa crítica vai conduzir Husserl a reelaborar o conceito de totalidade de tal modo que a consciência apareça "como uma totalidade sem nenhum equivalente entre as coisas" ${ }^{23}$. $\mathrm{Ou}$, mais precisamente, essa crítica prepara justamente aquilo que Merleau-Ponty quer evitar: a redução a uma consciência transcendental pura. Daí porque ele chama a atenção para aquele outro aspecto da forma, para sua "verdade fenomenológica", que Husserl teria deixado escapar. E este aspecto consiste justamente na junção da idéia e da existência, do inteligível e do sensível, o que se vê pela "organização intrínseca" da forma, pela ausência, nela, de "eventos exteriores uns aos outros, sem laço interno". Quer dizer, essa nova totalidade, que não se confunde com um agregado, implica uma significação que não lhe vem de fora, que lhe é imanente; daí justamente porque não é mais necessário o recurso a uma subjetividade — ou a qualquer outro princípio - que seria a fonte desta significação. A forma traz um sentido que não é produto de uma atividade do espírito sobre materiais exteriores, ela implica uma "organização espontânea para além da distinção entre a atividade e a passividade"; esse sentido é "autóctone", ele advém da organização interna dos elementos ${ }^{24}$, o que significa dizer que, no interior dela, tais elementos não

22 MERLEAU-PONTY. La structure..., p. 223.

23 MERLEAU-PONTY. Les sciences de l'homme et la phénoménologie, p. 17.

24 Ibidem, p. 37.

25 MERLEAU-PONTY. Phénoménologie..., p. IV; 5. 
têm existência separável, não são ligados de fora. A forma vai implicar então uma intencionalidade distinta daquela que resulta de uma pura consciência, da intencionalidade de ato "que faz o mundo repousar na atividade sintética do sujeito" 25 , que faz do Espírito a fonte da significação ${ }^{26}$. A forma, porque envolve uma significação imanente, uma organização espontânea, pode prescindir da passagem a um sujeito transcendental, doador de sentido - embora ela envolva um sujeito, mas que não é fonte de significação. O que Merleau-Ponty vê na Gestalttheorie é portanto, antes de mais nada, uma alternativa ao idealismo, inclusive ao idealismo husserliano.

A significação imanente da forma a aproxima do modelo da terceira Crítica, aquele que aponta um livre acordo entre o sensível e o conceito. De modo que, se é verdade, de um lado, que Kant, na história traçada por Merleau-Ponty, pertence à galeria dos intelectualistas, ao lado de Descartes, é verdade também, de outro lado, que o próprio Kant aponta a superação do modelo intelectualista na terceira Crítica (como Merleau-Ponty pretende fazê-lo por relação ao Husserl intelectualista), na medida em que ele aí descobre um juízo "que faz nascer no objeto individual seu sentido e não lhe traz inteiramente feito" ${ }^{27}$. MerleauPonty cita a Crítica do juízo: "(a faculdade de julgar) 'deve portanto ela mesma dar um conceito, que na realidade não faz conhecer coisa alguma, e que serve de regra apenas para ela, mas não de regra objetiva à qual adaptar seu juízo; pois agora seria preciso uma outra faculdade de julgar para poder discernir se se trata ou não do caso em que a regra se aplica" 28 . Kant abre um domínio em que a significação não é ainda exterior ao sensível, não é ainda posta por uma consciência naturante, mas "nasce no objeto individual" — o que, no modelo merleau-pontiano, vai conduzir à autonomia da percepção por relação a uma consciência determinante, a uma consciência que teria, ela, "uma função universal de organização da experiência" 29 . Kant, finalmente, abre a via de um projeto genético, de busca da "gênese do sentido"30 — projeto que será o de Merleau-Ponty. Ora, mas justamente aí Merleau-Ponty não se afasta, ainda uma vez, de Kant, por pretender flagrar, na percepção, "a inteligibilidade em estado nascente" 31 ? Justamente isso não aponta para um acordo diferente mesmo do da terceira Crítica? Não é afinal no mínimo questionável que a "Analítica

\footnotetext{
26 Trata-se aqui, evidentemente, de uma oposição entre a intencionalidade de ato (noética) e a intencionalidade operante (noemática).

27 Ibidem, p. 53; 74 (grifos nossos).

28 Ibidem, p. 53; 618 (citação do Prefácio).

29 MERLEAU-PONTY. La structure..., p. 186.

30 MERLEAU-PONTY. Phénoménologie..., p. XIV; 17.

31 MERLEAU-PONTY. La structure..., p. 223.
} 
do belo" nos ofereça algo como a junção de uma idéia e de uma existência, que o acordo aí em questão nos mostre um sentido nascendo em um objeto individual?

Parece que sim, pois, afinal, o sentimento de prazer e desprazer não designa absolutamente nada no objeto, apenas a maneira pela qual o sujeito sente-se a si próprio quando é afetado pela representação ${ }^{32}$. Essa redução ao elemento subjetivo parece ausente da percepção merleau-pontiana, que pretende flagrar no percebido a junção da idéia e da existência. E é essa posição de existência que parece suspensa em Kant, na medida em que o prazer não é determinado pela existência física do objeto: "se a questão é se algo é belo, não se quer saber se, para nós ou para quem quer que seja, importa algo a existência da coisa, ou sequer se pode importar; mas sim como a julgamos na mera consideração" 33. A redução ao subjetivo busca neutralizar o fato, que passa a exprimir apenas "um direito que a análise deve reencontrar" 34 , de modo que o sujeito transcendental, seja ele sujeito reflexionante ou sujeito de entendimento, permanece sempre "um protocolo de condições de possibilidade (da beleza ou da objetividade), e é impossível, em última instância, encontrar na terceira Crítica a doutrina do sujeito encarnado que aprofundaria a do sujeito puro [...]"35. Se essa leitura é mais adequada ao texto kantiano, então o acordo de que fala Merleau-Ponty não se passa, em Kant, lá no mundo percebido, ou melhor, na relação sujeito-objeto; ele não envolve, em suma, a existência da coisa; daí porque a desconfiança kantiana, frisa Lebrun, "em relação a toda ontologia prévia"36; antes, ao contrário, o problema, em Kant, da relação sujeito-objeto "tende a interiorizar-se", de modo que ela "se converte no problema de uma relação entre faculdades subjetivas que diferem em natureza" (sensibilidade, entendimento, imaginação) ${ }^{37}-\mathrm{o}$ que é substancialmente diferente do acordo buscado por Merleau-Ponty, em que o sentido se asssenta no fato, entrelaça-se ao sensível; já em Kant "é sempre uma espontaneidade escondida que o inventa" ${ }^{38}$. Tratar-se-ia então,

\footnotetext{
32 KANT. Analítica do belo. In: Crítica do juízo, \#1.

33 Ibidem, \#2.

34 LEBRUN. Kant e o fim da metafísica, p. 463.

35 Ibidem, p. 463.

36 Ibidem, p. 466.

37 DELEUZE. A filosofia crítica de Kant, p. 22. (nas referências consta apenas a tradução em português) Segundo Deleuze, "o problema de uma harmonia das faculdades é tão importante que Kant tem tendência a reinterpretar a história da filosofia na sua perspectiva". Cf. Carta a Herz de 26 de maio de 1789: "Estou persuadido de que Leibniz, com a sua harmonia preestabelecida, que ele estendia a tudo, não pensava na harmonia de dois seres distintos, ser sensível e ser inteligível, mas na harmonia de duas faculdades de um único e mesmo ser, no qual sensibilidade e entendimento se conciliam para um conhecimento de experiência". apud Deleuze, ibidem, p. 30.

38 LEBRUN. Kant..., p. 463.
} 
para Kant, não apenas na primeira mas também na terceira Crítica, de "recensear as condições sem as quais nossas pretensões de fato seriam injustificáveis" ${ }^{39}$, e não, como supõe Merleau-Ponty, de "definir nossos poderes de conhecimento por nossa condição de fato"40 — leitura que Merleau-Ponty supõe válida, evidentemente, apenas para a terceira Crítica, na medida em que ele vê nesta última a superação do intelectualismo da primeira.

Assim, o modelo de Merleau-Ponty parece mais próximo do da Gestalttheorie do que modelo kantiano, o que é ressaltado na defesa que ele faz de Koffka face às críticas de Husserl. Koffka tinha razão, aos olhos de MerleauPonty, em reagir às acusações de Husserl de que a Gestalttheorie é "psicologista": se é verdade que não se pode fundar a lógica, válida universalmente, em atos psíquicos individuais, isto é, se é verdade que não se pode fundar o direito no fato, e se o psicologismo é a tentativa de fazê-lo, então, reagia Koffka, a Gestalttheorie não é psicologista. Pois a crítica de Husserl se assenta no pressuposto de que as relações psicológicas são meramente fáticas ou externas. No entanto, como se trata de uma forma, os processos que compõem tal forma "são organizados segundo relações intrínsecas ou internas" — e, por isso mesmo, lembra Merleau-Ponty, "psicologia e lógica, existência e subsistência, realidade e verdade, não pertencem a domínios ou universos racionais totalmente distintos, entre os quais não haveria nenhuma relação inteligível"41 . A crítica de Husserl incidiria sobre a tentativa de fundar a significação em fatos despidos de qualquer significação; daí a necessidade, em Husserl, de despsicologizar o sujeito fundador ${ }^{42}$. A forma, entretanto, é já impregnada de significação, ela é "junção de idéia e existência” e, por isso, não há o problema da passagem do simples fato ao direito, pois já não lidamos com dois universos radicalmente distintos, entre os quais não haveria "relação inteligível".

Contra todo idealismo, Merleau-Ponty sustenta, portanto, as virtudes da forma. No entanto, a Gestalttheorie, também ela, termina por incidir em psicologismo, na medida em que ela realiza a forma, em que a toma como um

39 Ibidem, p. 464.

40 Ibidem, p. 464; MERLEAU-PONTY. Phénoménologie..., p. 255.

41 Apud MERLEAU-PONTY. Les sciences de l'homme..., p. 37. Cf. também KOFFKA. Principles..., p. 661.

42 Por essa mesma razão, Husserl constata a necessidade de abandonar o "prejuízo aristotélico", segundo o qual a única forma de existência admissível é a individual. Por isso ele introduz as essências, "objetos universais onde se buscará a 'base' da abstração dos conceitos" (Cf. MOURA. Crítica..., p. 111). O filósofo que persiste no projeto de fundação dos conceitos já não retornará aos atos da consciência, mas à essência deles, e assim a base se universaliza, de modo que, sublinhando a diferença entre eidos e fato, Husserl pretende escapar ao psicologismo. De resto, mesmo prejuízo também se encontraria no empirista, que, também segundo Husserl, simplesmente ignora a objetividade ideal, por preconceito nominalista, "por temor de ressuscitar as entidades 'metafísicas"', simplesmente recusa o geral, o universal, e não reconhece senão representações singulares, que utilizaríamos como se fossem gerais. Cf. LEBRUN. David Hume dans l'album de famille husserlien, p. 47. 
"acontecimento da natureza"43 : a Gestalttheorie recai em postulados realistas e deixa escapar a "verdade fenomenológica" da forma — o que, para MerleauPonty, não é nada surpreendente, já que se trata ali de uma psicologia, e não de uma autêntica filosofia, isto é, de vez que se trata ali de objetivar certos fatos empíricos, e não de mostrar a gênese do sentido e os fundamentos da racionalidade. Tudo se passa como se a psicologia da forma não tivesse sabido ver nesta todo o seu alcance "filosófico". Ela será ainda "psicologista", o que significa dizer: ainda presa de "postulados realistas". Apenas na filosofia, isto é, apenas para além da psicologia, esse alcance se revela e a integração pode ser feita: "a forma só pode ser plenamente compreendida e todas as implicações dessa noção só podem ser tiradas por uma filosofia que se libertaria dos postulados realistas que são aqueles de toda psicologia" ${ }^{44}$. Pois, afinal, o ponto de vista da psicologia é aquele em que o comportamento aparece como "um acontecimento do mundo, [...] realmente contido em um setor do espaço e em um segmento do tempo", em que a forma aparece como "uma causa ou uma coisa real" ${ }^{45}$. Ora, ao fazer isso, a Gestalttheorie compromete o que para MerleauPonty é o maior benefício da forma: o de que ela nos traz um tipo de unidade, de totalidade, que não pode ser encontrada em um ser da natureza $a^{46}$. Será esse o prejuízo da teoria da forma: "ao invés de se perguntar que tipo de ser pode pertencer à forma" - tarefa crítica da filosofia —, ela simplesmente coloca a forma "no número dos acontecimentos da natureza". Com isso, a Gestalttheorie é vítima, também ela, do prejuízo objetivista, prejuízo compreensível, uma vez que ela é ciência. Caberá à filosofia fazer aquela indagação e superar o prejuízo objetivista inerente a toda ciência; apenas ela, não comprometida com postulados realistas, pode recuar um passo e perguntar que tipo de ser é esse que subverte as categorias clássicas de sujeito e objeto e se apresenta como uma mistura de ambos - em vez de simplesmente lançá-lo no mundo como ser real. Uma filosofia da forma precisará, por isso, antes de mais nada, abandonar todo postulado realista - ainda que se postulem não átomos, mas estruturas complexas - e perguntar pelo tipo de ser da forma, em vez de tomá-la como ser real. Para Merleau-Ponty, é só então que a verdadeira "significação filosófica" da forma vai se revelar. Daí porque o problema de Merleau-Ponty está para além de qualquer psicologia: "[...] se a unidade do mundo não está fundada na unidade da consciência, se o mundo não é o resultado de um

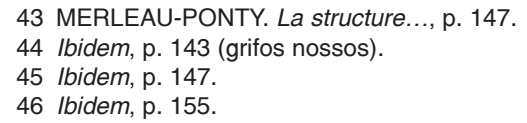


trabalho constitutivo, de onde provém que as aparências sejam concordantes e reúnam-se em coisas, em idéias, em verdades - por que nossos pensamentos errantes, os acontecimentos de nossa vida e os da história coletiva pelo menos em certos momentos adquirem um sentido e uma direção comuns e se deixam apreender sob uma idéia? Por que minha vida consegue retomar-se a si mesma e projetar-se em falas, em intenções, em atos? Este é o problema da racionalidade" 47 .

\section{IV}

A teoria da forma põe em relevo a questão relativa a um ser que ultrapassa os dualismos clássicos e, nessa medida, ela permite retomar o problema da racionalidade de maneira mais radical do que o fizera o idealismo. A partir daqui, Merleau-Ponty poderá apontar o prejuízo radical que se esconde por trás deste último, aquilo que lhe passa inteiramente despercebido. O idealismo permanece numa atitude "dogmática", diz ele ${ }^{48}$, justamente porque aceita sem mais a idéia do verdadeiro e a idéia do ser, porque não viu que a tarefa da filosofia é fazer a "genealogia do ser" ${ }^{49}$; daí porque parte diretamente para a busca das condições que o tornam possível, sem questionar sua origem. Não é de estranhar que a percepção passe a ser construída pela junção dessas condições de possibilidade, quando, em verdade, é nela que flagramos o momento originário e, por isso, é dela que deve se ocupar a filosofia que retoma radicalmente o problema da racionalidade: "a percepção como encontro com as coisas naturais está no primeiro plano de nossa pesquisa, não como uma função sensorial simples que explicaria as outras, mas como arquétipo do encontro originário" 50 .

Já na Estrutura do comportamento, Merleau-Ponty se impunha a tarefa de realizar uma fenomenologia da percepção. E essa tarefa se impunha porque a percepção, ou mais especificamente, o mundo percebido, fazia as vezes daquele originário, da instância a partir da qual se pode ver "nascer o sentido", instância "anterior ao número, à medida, ao espaço, à causalidade" e através da qual deve ser "apreendido o mundo intersubjetivo de que as ciências, aos poucos, precisam as determinações" ${ }^{51}$. Em $O$ primado da percepção, MerleauPonty precisa um pouco mais o que ele tanto espera da percepção - essa que,

\footnotetext{
47 MERLEAU-PONTY. Phénoménologie..., p. 467; 547-548.

48 Ibidem, p. 49, 69; 40, 60.

49 Ibidem, p. 67; 86.

50 MERLEAU-PONTY. Le visible..., p. 210.

51 MERLEAU-PONTY. La structure..., p. 236.
} 
na feliz expressão de Frédéric Worms, é a “via real” de Merleau-Ponty. E acrescentaríamos: é a "via real" que leva ao originário, ao primitivo, razão pela qual ela "não é uma questão local, mas envolve todas as dimensões da experiência"52. "Falando em um primado da percepção", diz Merleau-Ponty,

jamais pretendemos dizer (o que seria voltar às teses do empirismo) que a ciência, a reflexão, a filosofia fossem sensações transformadas [...] Exprimíamos nesses termos que a experiência da percepção nos repõe em presença do momento em que se constituem para nós as coisas, as verdades, os bens, que ela nos entrega um logos em estado nascente, que ela nos ensina, para além de todo dogmatismo, as condições verdadeiras da objetividade [...] Não se trata de reduzir o saber humano ao sentir, mas de assistir ao nascimento desse saber, de torná-lo para nós tão sensível quanto o sensível, de reconquistar a consciência da racionalidade, que se perde acreditando que ela vai por si mesma, que, ao contrário, a reencontramos fazendo-a aparecer sobre um fundo de natureza inumana ${ }^{53}$.

E tampouco o recuo ao fenômeno deve nos fazer crer que a percepção se mova em um ambiente de indeterminação absoluta, que o mundo vivido seja sem qualquer relação com o mundo exato da verdade - ao contrário, o recuo ao pré-objetivo deve justamente mostrar a gênese do mundo objetivo, ou, mais precisamente, deve mostrar "a passagem do indeterminado ao determinado" 54 , a passagem efetiva e não meras condições de possibilidade do ser determinado. De modo que já na percepção flagramos essa passagem. Mais ainda: segundo Merleau-Ponty, a própria ordem pré-objetiva não apenas se "fixa" realizando-se na instauração da objetividade lógica, mas de fato é por essa instauração que ela começa a existir. Quer dizer, do mesmo modo que a idéia de uma gênese da verdade nos faz recuar a um mundo pré-objetivo, também o mundo pré-objetivo não seria senão um fluxo ininterrupto sem a objetivação — de modo que, no limite, não haveria consciência de coisa alguma ${ }^{55}$. Assim, o método indireto - partir dos seres (ou das objetividades) para chegar ao ser - assenta-se na natureza do ser, que sempre se objetiva e, por isso mesmo, é uma lei da ontologia ser indireta ${ }^{56}$. O prejuízo do mundo determinado não vem portanto da ciência; ao contrário, ele se assenta na própria percepção, é a

\footnotetext{
52 WORMS, Frédéric. In: MERLEAU-PONTY. Notes de cours sur l'Origine de la géométrie de Husserl, p. 195. 53 MERLEAU-PONTY. Le primat de la perception, p. 67-68.

54 MERLEAU-PONTY. Phénoménologie..., p. 39; 59.

55 Falando da consciência mítica, Merleau-Ponty observa que, embora essa consciência não coloque "diante de si termos definidos por um certo número de propriedades isoláveis e articuladas umas às outras", nem por isso ela "se arrebata a si mesma em cada uma de suas pulsações, sem o que ela não seria consciência de coisa alguma. Ela não toma distância em relação a seus noemas, mas se passasse com cada um deles, se não esboçasse o movimento de objetivação, ela não se cristalizaria em mitos" (Ibidem, p. 338; 392).

56 "É talvez uma lei da ontologia ser sempre indireta, e só conduzir ao ser a partir dos seres" (MERLEAUPONTY. Résumés de cours, p. 125.
} 


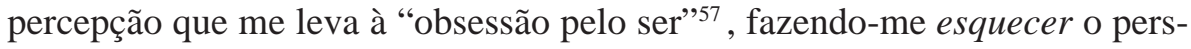
pectivismo de minha experiência efetiva - pois é a própria percepção que se orienta para um em si como para seu fim, é ela que se dá como percepção de um ser, e não por outra razão o objetivismo não acreditou necessário fazer uma genealogia do ser. De modo que desvelar os fenômenos é ir "contra o movimento natural do conhecimento, que atravessa cegamente as operações perceptivas para ir diretamente ao seu resultado teleológico"s8, é inverter esta inversão natural inscrita na própria percepção ${ }^{59}$. Daí porque é fácil ao senso comum dizer o que ele percebe: uma mesa, uma folha de papel, um livro etc. Mas desde que se recua aos fenômenos, desde que se recua do objeto percebido à percepção efetiva, "nada é mais difícil do que saber ao certo o que nós vemos" $"$. Mas é verdade também que atravessar as operações perceptivas não as anula, não as torna inexistentes, e que portanto a objetividade não deixa de ter sua origem no pré-objetivo. É o esquecimento que nos faz crer que a percepção é percepção de um ser, lançando no silêncio a história de sua constituição ${ }^{61}$, é ele que nos leva a pôr a determinação plena, o objeto - que, uma vez constituído, aparece então "como a razão de todas as experiências que dele tivemos ou que dele poderíamos ter"62. É o esquecimento da história dessa constituição que permite, por sua vez, o desenvolvimento do prejuízo do mundo e faz a percepção aparecer como uma "ciência iniciante", no sentido em que também ela se pautaria por determinações lógicas, como se a coisa, apresentando-se como o invariante da percepção, correspondesse ao conceito na ciência enquanto "meio de fixar e objetivar os fenômenos"63.

Ora, a história que o fenomenólogo entende retomar é justamente essa, a que nos leva à objetividade, é a história de sua constituição, objetividade que vem ao mundo quando a percepção "refaz os seus passos, os contrai e os fixa em um objeto identificável, passa pouco a pouco do 'ver' ao 'saber', e obtém a unidade de sua própria vida" ${ }^{64}$, quando ela retoma, "a cada instante, sua própria história na unidade de um novo sentido"65 — "novo" porque essa unidade idêntica foi constituída, e não dada de início. Justamente aí reside a "dimensão constitutiva" da percepção, constitutiva da objetividade, o que exi-

57 MERLEAU-PONTY. Phénoménologie..., p. 85; 108.

58 Ibidem, p. 71; 91.

59 MERLEAU-PONTY. La Structure..., p. 236.

60 MERLEAU-PONTY. Phénoménologie..., p. 71; 91.

61 "Mas se a essência da consciência é esquecer seus próprios fenômenos e tornar assim possível a constituição das "coisas'" (Ibidem, p. 71; 92).

62 Ibidem, p. 81; 103.

63 Ibidem, p. 66; 86.

64 Ibidem, p. 48; 68.

65 Ibidem, p. 39; 59 
girá certamente uma nova intuição do tempo capaz de responder a essa retomada direta do passado que permite constituir uma unidade, uma identidade - retomada que, justamente por concluir aqui em uma objetividade, termina por "contrair" a espessura da duração escoada, por "reunir" o que foi repartido em "vários pontos do tempo", reunião e contração que consistem justamente na passagem à objetividade: "quando eu me ponho a perceber esta mesa, contraio resolutamente a espessura da duração escoada desde que a olho, saio de minha vida individual apreendendo o objeto como objeto para todos, reúno então de um só golpe experiências concordantes mas separadas e repartidas em vários pontos do tempo" "66 . A história da constituição é a história da passagem da multiplicidade à identidade. Assim, em vez de dizer que a percepção é uma "ciência iniciante", o que lança sobre ela objetividades que em verdade ela constitui, será preciso dizer, ao contrário, que a ciência "é uma percepção que esquece suas origens e se crê acabada" ${ }^{67}$, já que não apenas a evidência da idéia tem mesma história que a da percepção, mas é uma história que a ciência ignora $^{68}$. O projeto de Merleau-Ponty é retomar esta história, lançar luz sobre ela, sobre o que permanece em silêncio, tornando a filosofia "não um certo saber, mas a vigilância que não nos deixa esquecer a fonte de todo saber" ${ }^{69}$. Não se trata de competir com a ciência, mas de situá-la — só assim se vai até as raízes do problema da racionalidade. O idealismo não viu que para ultrapassar o dogmatismo seria necessário voltar a esse momento originário e "desvelar a operação que torna [a percepção] atual ou pela qual ela se constitui" "70; o seu erro, o seu prejuízo maior, o que o leva a nos esconder o "núcleo vital da consciência perceptiva" é justamente o fato de ele "buscar as condições de possibilidade do ser absolutamente determinado"71 , passando em silêncio "o momento decisivo da percepção" (grifo nosso), que é o "surgimento de um mundo verdadeiro e exato"72, a passagem do indeterminado ao determinado.

66 Ibidem, p. 50; 71.

67 Ibidem, p. 69; 89.

68 "Eu não saberia que possuo uma idéia verdadeira se não pudesse, pela memória, ligar a evidência presente àquela do instante escoado [...] de forma que a evidência espinozista pressupõe aquela da recordação $e$ da percepção" (Ibidem, p. 49-50; 70).

69 MERLEAU-PONTY. La structure..., p. 138.

70 MERLEAU-PONTY. Phénoménologie..., p. 48; 68.

71 Ibidem, p. 55; 76.

72 Ibidem, p. 65; 85. 


\section{V}

Vimos que a tese idealista da relação entre sujeito e mundo implica para Merleau-Ponty uma dupla transposição: a transposição do sujeito encarnado em sujeito transcendental e da realidade do mundo em idealidade. Em 1938, a encarnação passa por uma reformulação das noções de corpo e alma, reformulação facultada pela noção de forma da Gestalttheorie. E Merleau-Ponty já apontava ali que esse problema, na perspectiva criticista, perspectiva que é a da consciência absoluta, "parece desaparecer" 73 . Contra a filosofia crítica, Merleau-Ponty já insistia em 1938 em passar ao largo de uma reflexão que tem por fim suprimir minha inerência a meu corpo; essa reflexão é uma espécie de "via curta", de atalho, que faz perder o essencial: a minha encarnação e a do mundo. Daí porque ele conclui A estrutura do comportamento lançando um projeto de trabalho segundo o qual "seria necessário definir novamente a filosofia transcendental de maneira a integrar nela o fenômeno do real" 74 .

A Fenomenologia da percepção dá o primeiro passo na consecução desse projeto. Será ainda uma reflexão que vai nos conduzir ao pré-objetivo, ao irrefletido, mas uma reflexão que não suprima a opacidade e portanto não nos instale em um ego cogito. A essa nova reflexão, Merleau-Ponty vai denominar "radical", precisamente porque ela tem em vista a encarnação, porque ela revela um sujeito originário que não é ainda consciência (mas tampouco é mecanismo). Daí o interesse de Merleau-Ponty pela patologia: "nossa inteligência de nós mesmos deve muito mais ao conhecimento exterior do passado histórico, à etnografia, à patologia mental, por exemplo, do que à elucidação direta de nossa própria vida" 75 . Quando o intelectualismo afirma que eu não poderia me perceber "circundado por meu corpo" se eu não pudesse pensar essa relação e assim escapar a ela no momento mesmo em que a represento ${ }^{76}$, ele torna o corpo uma idéia e rompe com a opacidade. Para Merleau-Ponty, ao contrário, a "reflexão radical" deve ser consciente "de sua própria dependência em relação a uma vida irrefletida que é sua situação inicial, constante e final" "77. É-lhe essencial reconhecer-se como "reflexão-sobre-um-irrefletido"78 — em vez de ultrapassá-lo e dissolvê-lo. Daí porque a análise da doença: a doença é o recurso que nos coloca diante do irrefletido, ou, se se quiser, diante do pré-objetivo - no caso, diante do sujeito encarnado, o verdadeiro sujeito de percepção.

\footnotetext{
73 MERLEAU-PONTY. La structure..., p. 218.

74 Ibidem, p. 241.

75 MERLEAU-PONTY. Parcours deux, p. 12.

76 MERLEAU-PONTY. Phénoménologie..., p. 47; 67.

77 Ibidem, p. IX; 11.

78 Ibidem, p. $76 ; 97$
} 
Ora, malgrado uma diferença de método e de alcance entre A estrutura e a Fenomenologia, elas estão de acordo no essencial, no que se refere à encarnação. A novidade da Fenomenologia é a introdução do tempo para pensar a relação entre o inferior e o superior, o corpo e a alma, relação que A estrutura pensa apenas em termos de forma (formas física, vital e humana) ${ }^{79}$. É então que Merleau-Ponty consegue ligar interiormente o "psíquico" e o "fisiológico". O inferior, a forma física, aquilo sobre o qual a existência pessoal vai se assentar tornar-se-á o passado, o sedimentado, devidamente engrenado à existência pessoal, que é a forma superior, e formando com ela um único ser. $\mathrm{O}$ "corpo atual", instalado no "presente vivo" e voltado para o mundo, para o porvir, arrasta atrás de si o sedimentado, que é o "corpo habitual", ambos, corpo habitual e corpo atual, passado e presente, engrenados e orientados, prospectivamente, para um pólo intencional. Daí o esforço de Merleau-Ponty em mostrar que esse sedimentado não é uma massa inerte no fundo de nossa consciência, que ele, ao contrário, se "alimenta secretamente" de meu presente ${ }^{80}$, formando com este uma unidade que não é mais a de substâncias ontologicamente distintas. Agora, a união corpo e alma, em si e para si, é a união de um passado que não é jamais completamente transcendido, que, por não ser ultrapassado completamente, é "assumido" e responde a determinadas situações e permanece, de algum modo, presente. O corpo habitual é essa "quasepresença" do passado; não é uma imagem que podemos evocar, não são traços gravados no corpo, não é, portanto, uma presença objetiva; essa existência habitual, anônima, pré-pessoal, não é uma coisa inerte, como o em si, mas esboça, também ela, o movimento de existência — o que só uma descrição da percepção como forma temporal permite mostrar. $\mathrm{O}$ meu presente assume o corpo habitual e o reintegra à existência pessoal, de modo que mesmo os reflexos não estão delineados em um fundo inerte, mas, também eles, "têm um sentido", também eles manifestam "o estilo de cada indivíduo"81, na medida mesma em que eles se inserem em uma situação presente, ou melhor, em que são retomados por uma situação presente, que, por sua vez, é voltada para o porvir. O meu passado só é passado porque é "retomado em um novo movimento" ${ }^{82}$, porque é assumido pelo presente. E esta relação é de mão dupla. $\mathrm{O}$ sedimentado, embora retomado pelo presente, é o solo sobre o qual se estabelece a consciência presente: "a consciência conserva atrás de si as sínteses

79 O tempo, como veremos, é a chave para pensar a dupla encarnação, a do sujeito e a do mundo - e sempre no nível da percepção.

80 Merleau-Ponty. Phénoménologie..., p. 101; 127.

81 Ibidem, p. 100; 126.

82 Ibidem, p. 151; 183. 
efetuadas, elas ainda estão disponíveis, poderiam ser reativadas"83 , de modo que "a consciência só é consciência de algo arrastando atrás de si seu rasto, [...] para pensar um objeto, é preciso apoiar-se em um 'mundo de pensamento' precedentemente construído" 84 . É essa a ambigüidade acarretada pela introdução do tempo como forma da experiência perceptiva: de um lado, o sedimentado se alimenta de meu presente, exprime a energia de meu presente, já que é retomado por ele; o ser no mundo, a partir de sua situação presente, dá sentido aos reflexos e assim os "funda"; de outro lado, e inversamente, é verdade também que meu presente se entrega aos reflexos, se assenta nesse solo constituído, e assim, para terminar, se funda neles ${ }^{85}$. Não se compreende o sedimentado sem o presente que o retoma, nem o presente, que é voltado para o porvir, sem um solo sobre o qual ele se funda, isto é, sem o sedimentado.

$\mathrm{O}$ meu corpo manifesta portanto uma ambigüidade. $\mathrm{O}$ corpo habitual e o corpo atual, a existência anônima e a existência pessoal aparecem como um único ser na medida em que são ambos orientados para um pólo intencional ou para um mundo - o que significa dizer que eles só aparecem a uma descrição da experiência efetiva de perceber. Eles se unificam nessa orientação. Pois, enfim, o corpo habitual, a existência anônima e geral é "assumida" pela existência pessoal e "reintegrada" a ela: o sedimentado é "retomado" pela situação, de modo que ele se alimenta do presente. E, reciprocamente, a existência pessoal nada seria se não dispusesse de nenhum meio de se efetuar, se não tivesse um solo sobre o qual se assentar. Daí porque Merleau-Ponty vai insistir que o corpo não é uma tradução, no exterior, de um estado interior, daí porque o corpo não manifesta, fora, o que se passa na consciência - o "interior" e o "exterior" se ligam aqui intimamente. De modo que, se o corpo exprime o espírito, "não é como os galões significam a graduação ou como um número designa uma casa". Antes, ao contrário, o signo deve ser "habitado" pela significação, como o corpo pela alma, "ele é de certa maneira aquilo que significa" ${ }^{\circ 6}$. É o tempo, portanto, a chave última da relação interna entre signo e

83 Ibidem, p. 156; 188.

84 Ibidem, p. 159; 191.

85 MERLEAU-PONTY. Phénoménologie..., p. 102; 128. Merleau-Ponty dirá que, ao contrário do que se poderia supor, é no homem que talvez encontremos reflexos puros, já que "ele é talvez o único a poder entregar isoladamente tal parte de seu corpo às influências do meio" (La structure..., p. 47). É como se, para alargar seu meio para além do atual, ele entregasse a uma parte de si mesmo a elaboração da resposta a cada questão que seu meio the oferece. Daí porque cada situação momentânea já não constitui para ele a totalidade do ser, cada estímulo já não esgota todo o seu campo prático; as respostas já estão aqui "desenhadas de uma vez por todas em sua generalidade" (Phénoménologie..., p. 103; 129). É à periferia de si mesmo que o sujeito confia a adesão pré-pessoal ao mundo.

86 MERLEAU-PONTY. Phénoménologie..., p. 188; 222-223. 
significado, é o tempo a chave da encarnação que a forma já anunciava - e ele traz consigo essa ambigüidade desconhecida pelo objetivismo. A unidade entre existência anônima e existência pessoal, entre corpo e existência nos assegura aqui o modelo de uma estrutura em que "o expresso não existe separado da expressão e em que os próprios signos induzem seu sentido no exterior" 87 - pois o corpo exprime a existência não como um número designa uma casa, mas na medida em que ela se realiza nele. E porque se trata aqui de unidade, torna-se impossível determinar o que se deve ao eu natural e o que se deve ao eu pessoal, ao corpo e ao espírito, à natureza e à liberdade - antes, ao contrário, essa estrutura se furta a toda determinação, a toda univocidade: "o equívoco", diz Merleau-Ponty, "é essencial à existência humana"88.

\section{VI}

É ainda o tempo que vai permitir a Merleau-Ponty comentar a segunda encarnação de que falamos, a do mundo percebido. Lembremo-nos do que dizíamos atrás, quando notávamos a objeção de Merleau-Ponty à tese idealista da constituição. Ali, o filósofo apontava não só a transposição do sujeito encarnado em sujeito transcendental, mas também a transposição da realidade do mundo em idealidade, em cogitatum. É essa segunda transposição que devemos discutir agora, de modo que a encarnação que queremos apontar não diz respeito apenas ao sujeito, mas também ao sensível, à coisa, de que o fenomenólogo costuma dizer que é dada em carne e osso na percepção.

Uma teoria do corpo implica numa teoria do sensível. É que o corpo, não sendo mais o corpo objetivo, arrasta "os fios intencionais que o ligam ao seu ambiente" e nos revela não só o sujeito que percebe, mas também o "mundo percebido" 89 . É o que permitirá a Merleau-Ponty pensar a síntese perceptiva sem um ato efetivo de ligação, sem uma potência ligante: o meu corpo, como sujeito de percepção, goza de um saber habitual do mundo, de uma "ciência implícita ou sedimentada" ${ }^{90}$ que torna prescindível aquela perene atividade de ligação. Se o corpo é o sujeito de percepção, então minha percepção "se beneficia de um trabalho já feito", de um passado que o intelectualismo com sua teoria da atividade de ligação ignora. Nosso olhar serve-se de um "saber latente", que "permanece sempre aquém de nossa percepção", mas que é retomado por ela - o que impede, definitivamente, que aquele que percebe 
seja "desdobrado diante de si como uma consciência deve estar"" : a "espessura histórica" envolvida na percepção nos impede de tomar o sujeito de percepção como transparência absoluta. Antes, ao contrário, toda percepção tem sempre "algo de anônimo". Nós nos confundimos com esse corpo habitual, que "sabe mais que nós sobre o mundo", somos com ele um único movimento: "eu vivo a unidade do sujeito e a unidade intersensorial da coisa, eu não os penso como o farão a análise reflexiva e a ciência" ${ }^{92}$. Mas, se não há uma atividade de ligação, como descrever a síntese perceptiva — síntese temporal que se consuma na coisa percebida?

A percepção "não faz atualmente a síntese de seu objeto"93 , não há uma consciência que constitua "atualmente o mundo que ela percebe" 94 . Para além dessa "atualidade" (que é, em verdade, uma atualidade não-temporal), há uma "pré-história" da percepção, pois há um sedimentado: a síntese não é feita atualmente, quer dizer, integralmente na atualidade, ela aparece pelo tempo a síntese atual se faz necessária, na perspectiva de Merleau-Ponty, apenas na medida em que o múltiplo aparece dissociado, objetivado, e ela será então apenas a contrapartida dessa análise ${ }^{95}$ — ou, se se quiser, apenas na medida em que ela já operou um corte entre o sensível e o inteligível. A síntese a que se opõe Merleau-Ponty é aquela feita integralmente na atualidade, necessária apenas como contrapartida de uma análise que dissocia o múltiplo; a síntese perceptiva, por outro lado, assenta-se em um solo, em um sedimentado e, por isso, ela se beneficia de um trabalho já feito, de um saber latente, de um passado - ou, se se quiser, ela se beneficia da crítica prévia à separação entre o sensível e o inteligível. A primeira síntese, como atividade efetiva de ligação, feita integralmente na atualidade, ignora o passado, isto é, o corpo, o sensível, e por isso ela é feita pela consciência, por um sujeito absoluto, em vez de aparecer pelo tempo. Sem esse passado, sem esse sedimentado, o intelectualismo, segundo Merleau-Ponty, precisa colocar uma subjetividade absoluta, de modo que, inversamente, a "presença" do passado permite que a percepção se faça pelo tempo, segundo "um encaixe e uma retomada das experiências anteriores nas experiências ulteriores", sem que isso implique "uma posse absoluta de mim por mim" 96 . A síntese perceptiva não é feita por um sujeito; ela produz um novo presente, enquanto retém o passado e, por isso mesmo, ela é 
"simultaneamente distendida e refeita pelo tempo". Vejamos como MerleauPonty descreve os momentos dessa síntese.

Não se pode rejeitar a síntese e dizer que a percepção "revela os objetos assim como uma luz os ilumina na noite" ou, como Malebranche, imaginar a alma saindo pelos olhos e visitando os objetos no mundo. Por que não? Porque, "para perceber uma superfície, por exemplo, não basta visitá-la, é preciso reter os momentos do percurso e ligar um ao outro os pontos da superfície" 97 . Para compreendermos o argumento de Merleau-Ponty, vejamos o que ele diz a propósito da visão binocular: o olhar, diz ele, se orienta para o objeto único como para a resolução de uma tensão, sente a diplopia como um desequilíbrio. Ora, um tal desequilíbrio não existe em si mesmo, pois "nas próprias retinas, consideradas como objetos, só existem dois conjuntos de estímulos incomparáveis"98; em outras palavras, o desequilíbrio só faz sentido para um sujeito, ou, mais precisamente, só faz sentido se o objeto único é já antecipado - o objeto único, portanto, não é mero efeito da convergência dos olhos -, pois é essa antecipação que torna a diplopia um desequilíbrio, não a representação do objeto único. O desequilíbrio não existe em si, mas para um sujeito que procura fundir os fenômenos monoculares e que tende à sinergia. Quer dizer, a unidade está ali "desde o momento em que as imagens monoculares se apresentam como "disparates" "99 — e justamente por isso elas se dão como disparates. Na medida em que a visão do objeto único não é efeito da fixação, mas é antecipada na fixação, podemos dizer que "a fixação do olhar é uma 'atividade prospectiva" "100 . Aqui, Merleau-Ponty pode introduzir a idéia de gênio perceptivo, aquele que tende sempre ao mais determinado.

Mas o ato do olhar não é apenas prospectivo; ele também é retrospectivo. Assim, por exemplo, um desenho perspectivo "não é percebido primeiramente como desenho em um plano, depois organizado em profundidade", pois a percepção em profundidade não é uma construção do entendimento, não é produto de uma relação de significação. Aqui, é o próprio "conjunto do desenho" que vai buscar "seu equilíbrio escavando-se segundo a profundidade", de modo que "é o próprio desenho que tende para a profundidade assim como uma pedra que cai vai para baixo"101. Nesse sentido, o ato do olhar aparece como "retrospectivo", pois o sentido do percebido, não constituído por mim, aparece

97 Ibidem, p. 279; 325.

98 Ibidem, p. 268; 311.

99 Ibidem, p. 303; 353.

100 Ibidem, p. 268; 311.

101 MERLEAU-PONTY. Phénoménologie..., p. 303; 353-354. 
como "instituído nele" 102 , de modo que eu não sou a origem solitária do sentido, mas apenas "reúno um sentido esparso por todos os fenômenos", eu apenas digo "aquilo que os fenômenos querem dizer de si mesmos": "toda fixação é sempre fixação de algo que se oferece como a ser fixado"103. O gênio perceptivo, ao assumir uma situação, dá a ela uma resposta que já está envolvida na questão. Por isso mesmo, a atividade do olhar é "retrospectiva", pois o objeto fixado se dá como anterior à fixação, como motivador dela ${ }^{104}$. Daí porque a resposta se dá como "irresistível" — ao menos quando se trata de um campo visual normal, não ambíguo: "quando passeio em uma avenida, não chego a ver os intervalos entre as árvores como coisas e as próprias árvores como fundo" "105, de modo que o gênio perceptivo aparece aqui finalmente como aquele que "sabe dar às coisas a devida resposta que elas esperam para existirem diante de nós". Assim, enquanto retrospectiva, a percepção fixa um objeto que já estava ali, um objeto natural, enraizado em um mundo natural. Mas justamente a fixação, a unidade da significação sensível que daí resulta (tratase de uma unidade aberta), não implica que tal unidade seja, se não nocional, ao menos intencional, e assim correlato de um sujeito? Como então falar de coisa natural? Como a coisa pode ser correlata de um sujeito, isto é, para nós, e natural, sempre já ali, isto é, em si? Essa "contradição" será reposta por Merleau-Ponty em termos temporais, não em termos "objetivistas"; por isso mesmo, ela poderá ser assumida como "definitiva", já que o próprio tempo implica uma semelhante "contradição". Vejamos de perto essa análise; é ela que vai nos mostrar como um comentário da experiência termina levando a um pensamento da omnitudo realitatis, e retoma, assim, o modelo da metafísica clássica que se começou, justamente, por abandonar.

102 Ibidem, p. 305; 355 (grifo nosso).

103 Ibidem, p. 305; 356.

104 "O que se entende por um motivo e o que se quer dizer quando se diz, por exemplo, que uma viagem é motivada? Entende-se por isso que ela tem sua origem em certos fatos dados, não que esses fatos por si sós tenham a potência física de produzi-la, mas enquanto eles oferecem razões para empreendê-la. $\mathrm{O}$ motivo é um antecedente que só age por seu sentido, e é preciso acrescentar que é a decisão que afirma esse sentido como válido e que lhe dá sua força e sua eficácia. Motivo e decisão são dois elementos de uma situação: o primeiro é a situação enquanto fato, o segundo a situação assumida [...] decidindo fazer esta viagem, eu valido esse motivo que se propõe e assumo essa situação. Portanto, a relação de motivante ao motivado é recíproca" (MERLEAU-PONTY. Phénoménologie..., p. 299-300; 348-349; grifo nosso): entre motivo e decisão, vemos pois, como já acontecia a propósito do sujeito de percepção, a relação de mão dupla que Husserl chamou Fundierung.

105 Ibidem, p. 304-305; 355. 


\section{VII}

O sujeito de percepção é o corpo, não uma consciência; daí porque o sensível pode "me convidar" a uma "focalização", a uma "fixação"; daí porque ele pode "despertar uma certa intenção motora", e ser "uma questão" à qual nossos sentidos "respondem exatamente"106. Daí porque eu não sou a fonte do sentido, mas apenas reúno um sentido já esparso pelos fenômenos. O sensível não é um espetáculo objetivo nem o correlato de uma consciência, pois a unidade está no termo de um movimento de fixação do corpo, e por isso mesmo tal unidade é intersensorial, não nocional: tal como os dois olhos colaboram na visão binocular, apreendendo um único objeto, do mesmo modo os sentidos se integram em uma única ação, como potências de um mesmo corpo, apreendendo uma única coisa, que é então uma coisa intersensorial. É verdade que não alcançamos jamais a ipseidade da coisa, justamente porque a síntese é temporal, mas é verdade também que os sentidos não representam aqui uma duplicação da realidade, uma realidade secundária; antes, ao contrário, eles são nosso acesso ao real, à coisa mesma: "eu atravesso as aparências"107 e chego à coisa real, o que se evidencia pelo fato de que a síntese, a unificação, motivada pela própria coisa, se faz lá nela mesma, não em um sujeito pensante, o que justamente caracteriza a síntese perceptiva e a distingue da síntese intelectual. E como termo de uma tal síntese, a coisa está aqui no horizonte aberto de uma experiência sinestésica. Os fantasmas, o ilusório, o engano, já não são uma realidade sensível comparada a uma realidade inteligível; a "plenitude de ser", o "ser verdadeiro"108 será aqui a coisa dada aos meus diferentes sentidos, quando ela chega ao seu "máximo de riqueza", quando os dados dos diferentes sentidos "são orientados para o pólo único"109, que polariza então nossa existência, e, por contraste, o fantasma será um reflexo ou um sopro leve do vento que se oferece apenas a um de meus sentidos (daí porque os fantasmas só se manifestam à noite, diz Merleau-Ponty ${ }^{110}$ ), e, para que o fenômeno se aproxime da existência real, ele precisará tornar-se capaz de "falar aos meus outros sentidos, como, por exemplo, o vento quando é violento e se faz visível na agitação da paisagem"; é assim que teremos a coisa "em pessoa", "em carne e osso". Daí a célebre referência de Merleau-Ponty a Cézanne: "um quadro contém em si até o odor da paisagem"111. Quer dizer: se a obra de arte retoma

106 MERLEAU-PONTY. Phénoménologie..., p. 366; 425.

107 Merleau-Ponty. Phénoménologie..., p. 367, 426.

108 Ibidem, p. 251; 293.

109 Ibidem, p. 368; 427.

110 Ibidem, p. 251; 293.

111 Ibidem, p. 368; 427. 
totalmente a coisa, então o que lá está deve conter respostas à interrogação de todos os meus sentidos, como acontece com a coisa "em pessoa". Vem daí que o real se encontre "carregado de predicados antropológicos", já que todas as relações que nele podemos assinalar se acham "mediadas por nosso corpo". Entendamos: o que antes parecia ser a coisa em si, a coisa mesma, não uma realidade duplicada, revela-se agora, também, como para nós, pois, se ela se mostra carregada de predicados antropológicos, é porque ela se põe "na extremidade de um olhar ou ao termo de uma investigação sensorial que a investe de humanidade" 112 .

Entretanto, a coisa não é apenas o "termo de uma teleologia corporal" — pois a coisa nos ignora, ela repousa em si, ela se apresenta àquele que a percebe como coisa em si: "não começamos por conhecer os aspectos perspectivos da coisa; ela não é mediada por nossos sentidos, nossas sensações, nossas perspectivas, nós vamos diretamente a ela e é secundariamente que percebemos os limites de nosso conhecimento e de nós mesmos enquanto cognoscentes"113. Daí porque a síntese parece se fazer na própria coisa: o sentido da coisa se constrói "sob nossos olhos", autonomamente, e ele se confunde "com a exibição da coisa" " em vez de vir de fora ou de se esconder por trás dela: "o sentido de uma coisa habita essa coisa como a alma habita o corpo: ele não está atrás das aparências [...] ele se encarna" nela ${ }^{115}$. Vem daí a definição merleau-pontiana do "núcleo de realidade": "uma coisa é coisa porque, o que quer que nos diga, ela o diz pela própria organização de seus aspectos sensíveis. O 'real' é este meio em que cada momento é não apenas inseparável dos outros, mas de alguma maneira sinônimo dos outros, em que os 'aspectos' se significam uns aos outros em uma equivalência absoluta"116. Assim, embora a coisa, ao termo da exploração sensorial, esteja carregada de predicados antropológicos, ela não se reduz a um pólo de minha vida corporal, pois ela repousa em si mesma, ela nos ignora, ela está enraizada "em um fundo de natureza inumana", ela é natural. Eis, enfim, o problema a que nos referíamos, o do "em-sipara-nós": "como compreender ao mesmo tempo que a coisa seja o correlativo de meu corpo cognoscente e que ela o negue?"117.

Dizer que a coisa é correlato de meu corpo, dizer que eu percebo com o corpo significa dizer que eu não constituo a coisa, que eu não ponho "ativamente

\footnotetext{
112 MERLEAU-PONTY. Phénoménologie..., p. 370; 429.

113 Ibidem, p. 374; 434.

114 Ibidem, p. 373; 433.

115 Ibidem, p. 369; 428.

116 Ibidem, p. 373; 433 (tradução modificada).

117 MERLEAU-PONTY. Phénoménologie..., p. 375; 436.
} 
e por uma inspeção do espírito as relações de todos os perfis sensoriais entre si e com meus aparelhos sensoriais" "118. Daí porque Merleau-Ponty insiste em que é o próprio espetáculo que dá as "indicações" ao meu olhar: este apenas reúne um sentido esparso no espetáculo, reúne apenas o que se oferece para ser reunido. Ora, mas justamente mostrávamos que essa síntese, na medida em que requer a mediação do corpo, investe a coisa de "humanidade", carrega-a de predicados antropológicos. É certo contudo que a percepção "existe sempre no modo do "Se""119, que ela "atesta e renova em nós uma "pré-história"”. A percepção, dizíamos acima, goza de um "saber habitual do mundo", de um sedimentado que afasta a idéia de um sujeito que faça, ele mesmo, a síntese. Ora, é justamente por conta desse saber, dessa "ciência sedimentada" que Merleau-Ponty poderá dizer que "meu olhar 'sabe' aquilo que significa tal mancha de luz em tal contexto" ${ }^{120}$ : de fato, se na percepção $e u$ não faço "atualmente a síntese" do percebido, mas meu olhar "compreende a lógica da iluminação", é porque tal síntese "aparece pelo tempo", quer dizer, porque o corpo (ele, não eu como "sujeito autônomo") compreende essa lógica - e essa compreensão atesta justamente um saber sedimentado: a percepção, de uma vez por todas, "não é um ato pessoal". Ela retoma um saber adquirido, saber que nosso olhar utiliza e que a mergulha no anonimato: dizer que se percebe com o corpo significa justamente dizer que a percepção, "considerada em sua ingenuidade, não efetua ela mesma essa síntese, ela se beneficia de um trabalho já feito, de uma síntese geral constituída de uma vez por todas" ${ }^{21}$. Ora, que síntese geral é essa?

Ela implica que o saber sedimentado do corpo compreende não apenas uma certa lógica, esta lógica deste segmento do mundo, mas, antes disso, é toda a "lógica do mundo que meu corpo inteiro esposa"; daí porque "síntese geral", e daí a conclusão de Merleau-Ponty:

Ter sentidos, ter a visão, por exemplo, é possuir essa montagem geral, essa típica das relações visuais possíveis com o auxílio da qual somos capazes de assumir qualquer constelação visual dada. Ter um corpo é possuir uma montagem universal, uma típica de todos os desenvolvimentos perceptivos e de todas as correspondências intersensoriais para além do segmento do mundo que efetivamente percebemos ${ }^{122}$.

\footnotetext{
118 Ibidem, p. 376; 437.

119 Ibidem, p. 277; 322.

120 Ibidem, p. 377; 437.

121 MERLEAU-PONTY. Phénoménologie..., p. 275; 319.

122 Ibidem, p. 377; 437-438.
} 
Ter um corpo é ter uma ciência implícita, sedimentada, do mundo em geral, e de que uma coisa é apenas "uma das concreções possíveis". Essa montagem universal não se confunde com um conjunto de condições de possibilidade, à maneira kantiana, pela simples razão de que aqui "o mundo tem sua unidade sem que o espírito tenha chegado a ligar suas facetas entre si e integrá-las na concepção de um geometral"'123.

Mas, então, se eu tenho uma típica de quaisquer relações intersensoriais, de qualquer concreção possível, é porque o mundo conserva o mesmo estilo em todas elas, é porque ele se conserva o mesmo independentemente do desenvolvimento da percepção, pois já não há aqui uma subjetividade que legisle. E o mundo conserva o mesmo estilo para mim porque ele permanece, porque ele está aí desde sempre, desde a primeira percepção; essa permanência do mundo é a permanência da generalidade, do horizonte de toda percepção, do fundo de que todo percebido não é senão a figura. O mundo é uma generalidade permanente, um "imenso indivíduo do qual minhas experiências são antecipadamente extraídas" 124 . Se, momentaneamente, eu me absorvo em pensamentos e deixo de ouvir um burburinho, "no momento em que retomo contato com os sons, eles me aparecem como já estando ali, eu reencontro um fio que tinha deixado cair e que não está rompido"; se, aproximando-me de uma cidade de automóvel, eu a olho intermitentemente, meu campo visual de agora já não é o mesmo de antes, de modo que, se "eu uno as duas aparências", é porque "ambas são extraídas de uma única percepção do mundo, que conseqüentemente não pode admitir a mesma descontinuidade" ${ }^{125}$.

Essa generalidade permanente no horizonte de minha vida, essa omnitudo realitatis sempre em face de mim, não é uma significação comum a minhas experiências; antes, ao contrário, a unidade do mundo é comparável à unidade da coisa na visão binocular: "minhas experiências do mundo integram-se a um só mundo, assim como a imagem dupla desaparece na coisa única”. Assim, não posso dizer que minha visão atual seja limitada ao meu campo visual efetivo, e que, por exemplo, o lado oculto dessa lâmpada ou a paisagem por trás dessa colina sejam representados por mim, pois isso implicaria dizer que eles são apenas possíveis - o que é representado não está aqui diante de nós, eu não o percebo atualmente ${ }^{126}$. Tampouco posso dizer que eles são evocados ou antecipados por mim como percepções que necessariamente se produziriam

\footnotetext{
123 MERLEAU-PONTY. Phénoménologie..., p. 378; 438-439.

124 Ibidem, p. 378; 439.

125 Ibidem, p. 380; 441.

126 MERLEAU-PONTY. Le primat de la perception, p. 44.
} 
se eu girasse a lâmpada ou atravessasse a colina - eles seriam conhecidos, nesse caso, como conseqüência de uma lei, tal como a solução de um problema matemático. Entretanto, os lados ocultos da lâmpada, a colina por trás da paisagem, são apreendidos por mim como presentes, como já aí, ou, mais precisamente, como horizontes da lâmpada e da paisagem. Não é apenas o objeto, este objeto, que me é dado, mas o mundo inteiro, toda a omnitudo realitatis para a qual remete o objeto e da qual, afinal, ele é extraído. Quando fixo uma mesa, oriento-me em direção ao objeto determinado, mas remetendo-a ao seu lugar no mundo, de onde ela é extraída: a percepção é prospectiva, porque o objeto está no termo da fixação, e retrospectiva, porque ele se apresenta como já estando ali, como um objeto natural enraizado em um mundo natural - o que significa dizer que a percepção envolve o mundo natural. Meu corpo compreende toda a lógica do mundo para além desse segmento percebido aqui e agora, já que ele possui um saber sedimentado, uma típica, uma ciência implícita do mundo em geral. Correlativamente, a generalidade que é o mundo se estende para além deste campo efetivo de percepção, nos horizontes dele, como horizonte mundial da coisa percebida, como o "fundo de natureza inumana" de onde a coisa é tirada, extraída. Não há campo presente sem um vasto horizonte mundial para o qual ele remete. Não há uma presença em ato, pois os horizontes são abertos e a síntese perceptiva não pode ser jamais concluída.

Eis aqui, enfim, as condições para se afirmar aquela dupla encarnação, a do sujeito e a do sensível, tão insistentemente buscada por Merleau-Ponty. Só o tempo permite realizá-la, só o tempo tomado como "medida do ser" 27 . No modelo merleau-pontiano, só ultrapassamos o objetivismo se pensarmos a coisa e o mundo não no plano do ser, mas no plano do tempo. Daí as conclusões a que chega o filósofo e que lhe permitem objetar não só ao idealismo, mas também ao seu partido rival, o realismo: o presente, dirá ele, não equivale ao apresentado, não o esgota, pois a coisa não é presente sem horizontes, isto é, sem passado e sem futuro. E, inversamente, assim como não há presente sem passado, sem esse fundo sobre o qual ele se assenta, também o passado depende de uma retomada presente, ou, considerando-se o caso em tela: do mesmo modo que o presente não esgota o apresentado, também, inversamente, o apresentado só se apresenta por meio do presente. Assim, meu presente não esgota o apresentado, porque ele remete à transcendência dos horizontes (o que impede, definitivamente, de fazer da percepção, como o realismo, uma coincidência 
com a coisa $)^{128}$; o apresentado, por sua vez, carece de um presente, de um ponto de vista, pois

se a coisa e o mundo pudessem ser definidos de uma vez por todas, se os horizontes espaço-temporais pudessem, mesmo idealmente, ser explicitados e o mundo pudesse ser pensado sem ponto de vista, agora nada existiria, eu sobrevoaria o mundo e, longe de que todos os lugares e todos os tempos se tornassem reais ao mesmo tempo, todos eles deixariam de sê-lo porque eu não habitaria nenhum deles

(o que afasta, definitivamente, a síntese do idealismo, que supõe uma ubiqüidade efetiva e não apenas intencional $)^{129}$. Ao contrário do objetivismo, que impõe noções alternativas, Merleau-Ponty desvela uma ambigüidade que não impõe a escolha entre, de um lado, o inacabamento do mundo, o mundo em aberto, horizonte mundial, e, de outro, sua existência, sua presença - pois essa ambigüidade se resume àquela do tempo, que é um meio só acessível se nele ocuparmos uma situação e o apreendermos através dos horizontes dessa situação. Daí, finalmente, a chave para a compreensão da contradição do emsi-para-nós, mesma chave que nos permitiu, a propósito do sujeito, falar em atividade e passividade, corpo atual e corpo habitual, existência pessoal e existência anônima - contradição que, ao invés de cessar, deve se generalizar e que a análise da temporalidade nos mostra como "definitiva"130.

Mas, então, não é apenas a essa ambigüidade que o comentário merleaupontiano da percepção nos leva; é ainda, e sobretudo, à idéia de omnitudo realitatis, implicada pelo princípio de que o tempo é a medida do ser. Se esse modelo permite pensar uma relação interna entre o sensível e o inteligível, ele implica também nos reconduzir ao modelo da metafísica clássica. E não há nisso nada de surpreendente, pois, desde o começo, Merleau-Ponty já nos lembrava, na objeção ao intelectualismo cartesiano, que ele se colocava a tarefa de pensar a relação cujo fonte última Descartes remetia a Deus. E, de fato, essa é a tarefa da filosofia, segundo Merleau-Ponty: "para mim" diz ele, "a filosofia consiste em dar um outro nome ao que por muito tempo foi cristalizado sob o nome de Deus"131.

\footnotetext{
128 Ibidem, p. 376; 436

129 Ibidem, p. 382-383; 445

130 MERLEAU-PONTY. Phénoménologie..., p. 451; 527.

131 MERLEAU-PONTY. Parcours deux, p. 371.
} 


\section{Referências}

DELEUZE, Gilles. A filosofia crítica de Kant. Trad. Germiniano Franco. Lisboa: Edições 70, 1987.

DESCARTES. Meditações metafísicas. In : Descartes. Trad. J Guinsburg. e Bento Prado Júnior. São Paulo: Abril, 1983 (Os Pensadores).

KANT, I. Analítica do belo. In: Kant II. Trad. Rubens R. Torres Filho. São Paulo: Abril, 1984. (Os Pensadores).

KOFFKA, Kurt. Principles of Gestalt psychology. New York: Harcourt, 1935.

LEBRUN, Gérard. David Hume dans l'album de famille husserlien. Manuscrito, Campinas, V, n. 2, abril 1982.

. Kant e o fim da metafísica. Trad. Carlos Alberto Ribeiro de Moura.

São Paulo: Martins Fontes, 1993.

MERLEAU-PONTY, Maurice. Notes de cours sur 'L'origine de la géométrie' de Husserl. Paris: PUF, 1998. (Épiméthée). . Parcours deux. Paris: Verdier, 2000.

. Phénoménologie de la perception. Paris: Tel Gallimard, 1995.

. Fenomenologia da percepção. Trad. Carlos Alberto Ribeiro de Moura.

São Paulo: Martins Fontes, 1994.

. Le primat de la perception. Paris: Verdier, 1996.

. Résumés de cours. Paris: NRF Gallimard, 1968.

. Les sciences de l'homme et la phénoménologie. Paris: CDU, 1975.

. La structure du comportement. Paris: PUF, 1990.

. Le visible et l'invisible. Paris: Tel Gallimard, 1996.

MOURA, C. A. Ribeiro de. Crítica da razão na fenomenologia. São Paulo: Edusp/ Nova Stella, 1989. 